NBER WORKING PAPER SERIES

\title{
THE EFFECT OF INTERNAL MIGRATION ON LOCAL LABOR MARKETS: AMERICAN CITIES DURING THE GREAT DEPRESSION
}

\author{
Leah Platt Boustan \\ Price V. Fishback \\ Shawn E. Kantor \\ Working Paper 13276 \\ http://www.nber.org/papers/w13276 \\ NATIONAL BUREAU OF ECONOMIC RESEARCH \\ 1050 Massachusetts Avenue \\ Cambridge, MA 02138 \\ July 2007
}

This paper has benefited from the helpful suggestions of Jerome Bourdieu, Bill Collins, Larry Epstein, Claudia Goldin, Pierre-Cyrille Hautcoeur, Chris Hanes, Larry Katz, Tim Leunig, Bob Margo, Chris Minns, Andy Seltzer, Max Stephan Schultz, Gilles Postal-Vinay and seminar participants at the DAE-NBER Program Meeting, University of Georgia, Georgia State University, Emory University, Northwestern University, University of Chicago, All Souls College at Oxford University, London School of Economics and University of Paris. The views expressed herein are those of the author(s) and do not necessarily reflect the views of the National Bureau of Economic Research.

(C) 2007 by Leah Platt Boustan, Price V. Fishback, and Shawn E. Kantor. All rights reserved. Short sections of text, not to exceed two paragraphs, may be quoted without explicit permission provided that full credit, including $(\mathrm{C}$ notice, is given to the source. 
The Effect of Internal Migration on Local Labor Markets: American Cities During the Great Depression

Leah Platt Boustan, Price V. Fishback, and Shawn E. Kantor

NBER Working Paper No. 13276

July 2007, Revised August 2008

JEL No. J61,N32,R23

\title{
ABSTRACT
}

During the Great Depression, as today, migrants were accused of taking jobs and crowding relief rolls. At the time, protest concerned internal migrants rather than the foreign born. We investigate the effect of net migration on local labor markets, instrumenting for migrant flows to a destination with extreme weather events and variation in New Deal programs in typical sending areas. Migration had little effect on the hourly earnings of existing residents. Instead, migration prompted some residents to move away and others to lose weeks of work and/or access to relief jobs. Given the period's high unemployment, these lost work opportunities were costly to existing residents.

\author{
Leah Platt Boustan \\ Department of Economics \\ 8283 Bunche Hall \\ UCLA \\ Los Angeles, CA 90095-1477 \\ and NBER \\ lboustan@econ.ucla.edu \\ Price V. Fishback \\ Department of Economics \\ University of Arizona \\ Tucson, AZ 85721 \\ and NBER \\ pfishback@eller.arizona.edu
}

Shawn E. Kantor

School of Social Sciences, Humanities and Arts

University of California, Merced

P.O. Box 2039

Merced, CA 95344

and NBER

skantor@ucmerced.edu 


\section{Introduction}

The large flow of immigrants to the United States over the past three decades has renewed public debate about the economic costs and benefits of immigration. Do immigrants depress the wages of native workers? Do they use more public resources - including transfer payments, public schooling and emergency medical care - than they pay in taxes? Similar debates swept the nation during the Great Depression, although the primary concern at that time was not with foreign arrivals, given that immigration was limited by a strict quota system, but rather with internal migrants. The hostility of Californians toward migrants fleeing the Dust Bowl, vividly portrayed in John Steinbeck's novel The Grapes of Wrath, illustrates the depth of this social and economic concern. ${ }^{1}$

Our analysis of the effect of internal migration to major American cities in the 1930 s on the economic outcomes of existing residents suggests that Californian's concerns were not unfounded. We find that residents of high in-migration areas earned less, primarily due to fewer weeks worked during the year. They were also less likely to hold a public relief job, conditional on being out of work. That local labor markets responded to migration supply shocks through reductions in employment, rather than through lower wages, is consistent with the aggregate combination of sticky wages, job sharing, and high unemployment that was present throughout the Depression decade (Bernanke, 1986; Margo, 1993; Hanes, 1996). ${ }^{2}$

The 1930s are a unique laboratory for exploring the causal impact of migration on the labor market. Migrants are not randomly assigned to destinations, but rather tend to be attracted to cities with high wages or strong wage growth. Thus, migrants' location choices have the potential to obscure the effect of heightened competition in the labor market. During the Depression, many internal moves were motivated by negative shocks to a migrant's home 
economy. Because these moves occurred within the United States, we have a wealth of information about the economic conditions in sending areas which can be used to create an instrument for migration flows. In particular, we use data on a set of "push" factors - including weather conditions and the generosity of New Deal policies - to predict outflows from major US markets, which we then assign to destinations based on the geographic proximity between source-destination pairs. ${ }^{3}$

\section{Previous Work on the Economic Effects of Immigration}

One of the underpinnings of anti-migrant sentiment is the fear that new arrivals drive wages down (and the local cost of living up), lowering the standard of living for the existing population. In a basic model of the labor market, migration flows into a city represent an outward shift in the supply of labor. This supply shift would lead to an unambiguous decrease in wages, unless the new population increased the demand for locally-produced goods and services - and thus labor demand - sufficiently to offset the increase in labor supply. Because American cities are tied to integrated national market for products, it is likely that the supply effect dominates the increase in derived labor demand.

This proposition has been tested in the United States in a variety of historical periods. Goldin (1994) documents that the mass migration from Europe at the turn of the $20^{\text {th }}$ century led to a large reduction in the wages of native-born workers in high migration areas. ${ }^{4}$ Few studies using modern data - with the exception of Altonji and Card (1991) - have detected a wage response of this magnitude, and many find no effect on wages at all (for a survey of this literature, see Friedberg and Hunt, 1995). This disparity could reflect a true change over time in the response to a local shock - for example, a nationally integrated labor market may allow a 
local disturbance to dissipate more rapidly - or may simply be the result of differences in available measures and research design.

The weakness of the relationship between immigration and wages in port-of-entry labor markets has prompted an on-going discussion about other margins along which local areas may adjust. Borjas, Freeman and Katz (1997) point out that if new arrivals to a city induce some of the existing workforce to relocate, these out-migrants will spread the economic costs of immigration to other markets. More generally, with the free flow of factors between cities, the initial wage and/or employment response to a labor supply shock might be tempered by the outmigration of labor or the in-migration of capital (Blanchard and Katz, 1992). Thus, the downward pressure of immigration on wages at the national level might be larger than comparisons of local labor markets would suggest (Borjas, 2003; Ottaviano and Peri, 2006). ${ }^{5}$

The empirical evidence on such factor mobility is mixed. Filer (1992) finds that immigrants crowd out existing workers on a one-for-one basis. However, more recent studies have not detected an appreciable out-migration response to international arrivals (see Card, 2001; Wright, Ellis and Reibel, 1997; and Kritz and Gurak 2001). ${ }^{6}$ On the capital side, Lewis $(2003,2004)$ proposes that local labor markets have adjusted to low-skilled immigrants through slower adoption of skill-biased computer and information technology.

Building on this recent work, we provide a comprehensive picture of local adjustment to internal migration during the Great Depression. To that end, we examine not only the wages and employment rates of local workers, but also the out-migration of existing residents and the creation of new establishments.

\section{Data on Internal Migration and Labor Market Outcomes in the 1930s}




\section{A. Internal Migration}

The 1940 Census was the first to gather systematic information on internal mobility in the United States. Respondents were asked to report both their current location in 1940 and their place of residence in 1935 . We use aggregate data on population flows to calculate fiveyear migration rates at the city level, or the number of migrants arriving in (or leaving) a city between 1935 and 1940 as a share of the existing population. ${ }^{7}$ In contrast, other studies typically proxy for a migration shock with the change in the share of the population that is foreign-born, a measure that does not account for possible outflows of the native population in response.

In- and out-migration flows are available for the 86 cities that had more than 100,000 residents in 1940. Whenever possible, we further aggregate the city data to match Standard Metropolitan Areas (SMA). Because some SMAs are anchored by multiple central cities - for example, Oakland and San Francisco, CA - we are left with 73 metropolitan areas, 69 of which have complete data. ${ }^{8}$ While migration counts are available by gender and race, we do not analyze the effect of female migrants because of their low labor force participation rates during this period. Because black migration is highly skewed towards a few large cities, we combine data on black and white men into a single flow. Our male migration rates includes movers of all ages, some of whom may have been too young or too old to participate in the labor market.

\section{B. Economic Outcomes}

We use individual records from the Integrated Public Use Microdata Series (IPUMS) to construct a sample of non-migrants residing in the metropolitan areas of interest in 1940 (Ruggles and Sobek, 2003). Our attention is limited to men between the ages of 18 and 65, who 
were not self-employed, living in group quarters, in the armed forces, or currently enrolled in school. $^{9}$

We explore the effect of net migrant arrivals on three spheres of economic activity: employment, earnings and out-migration. Following the practice of Depression-era statistics, we define employment as holding a private sector or non-relief public sector job (Lebergott, 1964; Darby, 1976). We investigate two forms of non-employment: holding a relief job and being idle (that is, being unemployed or out of the labor force). Annual earnings and its subcomponents - weekly wages and weeks worked during the past year - are computed for men who report being employed at the time of the Census, working a positive number of hours in the past week, and earning a positive income in the past year. ${ }^{10}$ We also measure hourly wages, but these results are particularly subject to measurement error given that hours are only reported for the Census week. To examine the mobility response of existing residents to new arrivals, we define an indicator equal to one for men who were living in a sample metropolitan area in 1935 but were no longer resident by 1940.

The micro data has three key advantages over local area aggregates. First, aggregate earnings data are only available at the local level for three sectors - manufacturing, retail and wholesale trade - whereas the micro data encompasses the whole labor market. Secondly, we can control for key determinants of wage and employment outcomes at the individual level, including age, education and race. This adjustment might prove important if selective outmigration changes the composition of the remaining labor force. Finally, we can directly exclude in-migrants from the sample. Our estimates can then be interpreted as a treatment effect of migration on the existing workforce, rather than a compositional change in the labor force as new workers arrive. ${ }^{11}$ 
Summary statistics at the metropolitan area level are presented in Appendix Table 1. The mean in-migration rate of 5.1 percent is low by historical standards. The Depression dampened geographic mobility, with interstate migration rates in the 1930s far below levels set ten years later during World War II (Rosenbloom and Sundstrom, 2004). The weak economic outcomes suggested in the data are characteristic of the period. 78.5 percent of men in the average metropolitan area were employed, compared to 84.7 percent in 1950. 24.1 percent of men who were out of work held a government relief job.

Before turning to a more formal analysis, the scatter plots in Figures 1a-1c depict the relationship between in-migration to a metropolitan area between 1935 and 1940 and the change in annual earnings in the manufacturing, wholesale, and retail sectors over the period. Earnings are calculated by dividing the total wage bill by the number of employees in the sector. Given that over half of employed men in our sample metropolitan areas worked in one of these three sectors, these figures provide a useful preview. In-migration is associated with reductions in annual earnings in manufacturing and wholesale trade, but has no relationship with earnings in the retail sector. ${ }^{12}$ Miami and San Diego are obvious outliers, with inmigration rates of 18.4 and 16.3 percent, respectively. Without these two areas, the strong relationship between migration and earnings in wholesale trade is weakened, but does not disappear. In our estimations below, we will take a broader view, examining earnings and employment in the labor market as a whole.

\section{Estimating the Relationship between Internal Migration and Economic Outcomes}

\section{A. OLS Specification}


We are interested in the effect of internal migration to a metropolitan area on the employment rate, annual earnings, and out-migration rate of existing residents. Let $\mathrm{Y}_{i j r, 40}$ represent an economic outcome for a non-migrant $i$ who lives in metropolitan area $j$ in region $r$ in 1940. We posit that $\mathrm{Y}_{i j r, 40}$ will be a function of the migrant-induced change in labor supply:

$$
\mathrm{Y}_{i j r, 40}=\alpha+\beta m_{j r, 40-35}+\gamma o_{j r, 40-35}+\Psi^{\prime} \mathrm{X}_{i j r, 40}+\Phi^{\prime} \mathrm{Y}_{j r, 35}+\Pi_{\mathrm{r}}+\varepsilon_{i j r, 40}
$$

where $m_{j r, 40-35}$ represents the in-migration rate to area $j$ and $o_{j r, 40-35}$ represents the outmigration rate from that area. In the earnings or employment equation, we expect $\beta$ to be negative and $\gamma$ to be positive. The most flexible specification, presented here, allows in- and out-migration to have distinct effects on labor market outcomes. For parsimony, we often restrict arrivals and departures to exert equal and opposite effects by including the net migration rate on the right-hand side $\left(n_{j, 40-35}=m_{j, 40-35}-o_{j, 40-35}\right)$.

$\mathrm{Y}_{i j r, 40}$ measures the level of earnings or employment of individuals in city $j$ in 1940 . The equilibrium wage level in an area is a function of the total labor supply, which is in part determined by the stock of internal migrants. However, our migration variables measure the flow of new arrivals. Ideally, we would use changes in earnings or employment as dependent variables. However, the 1940 Census was the first to ask such detailed questions about economic activity. Instead, we include aggregate wage or employment measures from 1935 among our set of regressors $\left(\mathrm{Y}_{j r} 35\right)$ and interpret the estimating equation as a quasi firstdifference. Specifically, in our wage and earnings regressions, we control for the logarithm of annual earnings per employee in manufacturing, retail and wholesale trade in 1935. In our employment regressions, we include the share of the city's population that was on work relief in October 1933 or that was unemployed in 1937. These measures are drawn from the Federal 
Emergency Relief Administration's Unemployment Relief Census for October 1933 and the Census of Partial Employment, Unemployment and Occupations (1938). ${ }^{13}$

In addition to initial wage or employment levels, we also control for the share of the city's population that was black, foreign-born, or illiterate, and the age distribution of the population in $1930 .{ }^{14}$ The micro data allow us to enter a series of individual characteristics $\left(\mathrm{X}_{i j r}, 40\right)$, including race, a cubic polynomial in age, and a set of education dummies for each year of completed schooling. Finally, because the extent of the downturn during the Depression varied geographically, we include a set of regional dummy variables $\left(\Pi_{\mathrm{r}}\right)$ (Wallis, 1989;

Rosenbloom and Sundstrom, 1999).

Errors are clustered at the metropolitan area level to allow for correlation in economic shocks faced by individuals in the same labor market. Although we are using individual-level data, our goal is to examine the impact of mobility on a local labor market. Thus, we weight individual observations from metropolitan area $j$ by the inverse of the area's total number of observations allowing each metropolitan area to contribute equally to the estimation.

\section{B. Developing an Instrument for Migration Rates}

Our primary concern in interpreting the sign and magnitude of the migration coefficients $(\beta$ and $\gamma)$ is that migrants are attracted to areas with high wages or strong employment performance. Consider an unmeasured, and thus omitted, city characteristic $c$ that belongs in equation 1 and that results in an increase in average wages between 1935 and 1940 . If $c$ also attracts migrants to the area, the coefficient on the in-migration rate $(\beta)$ will be biased upward and the coefficient on the out-migration rate $(\gamma)$ will be biased downward. We aim to 
design instruments for the in- and out-migration rates to an area $j$ that are uncorrelated with local economic conditions.

We use features of the migration decision to build an instrument. Prospective migrants from a source area $k$ compare the expected benefits of moving to new locations $j(j \neq k)$ with the costs of migration (Sjaastad, 1962). While benefits stemming from positive economic shocks in destination $j$ will undoubtedly be endogenous, benefits stemming from poor economic conditions in area $k$ are arguably exogenous to conditions in $j$. As a result, local economic conditions in areas that typically send migrants to a given city are natural instruments for inmigration to that city. The same argument can be made, in reverse, for out-migration.

We use weather shocks, variation in New Deal generosity, and other salient local factors (industrial structure, community characteristics) to predict out-migration from all source areas. We then assign predicted migrant flows to destinations using the geographic distance between source-destination pairs. For the instrument to be valid, the variables used to predict out-migration from sending areas must be uncorrelated with unobserved labor market conditions in destinations, except through migration. To the extent that internal migrants relocate over short distances, this assumption can be violated. ${ }^{15}$ Therefore, we construct our instrument using predicted migrant flows from outside of a destination city's own state in order to minimize concerns about the spatially correlated shocks. We also try restricting our attention to predicted migration from outside of a city's own Census region.

A related identification assumption pertains to the assignment of predicted migrants to destination cities. Actual settlement patterns may be correlated with unmeasured city characteristics because migrants are attracted to areas with strong economic conditions. Instead, we predict the probability that a migrant leaving area $k$ would settle in destination $j$ using only 
the geographic distance between $j$ and $k$ as the crow flies. ${ }^{16}$ Distance is a central determinant of a migrant's location choice (Borjas, 2001; Levy and Wadycki, 1974; Schwartz, 1976). Equally important, the distance between cities is invariant to contemporary economic conditions in either the sending or the receiving area, as population centers were established many decades before.

An example helps to illustrate this method. An extended period of drought and dust storms elevated the out-migration rate from Oklahoma during the 1930s (Gregory, 1989). Due to this economic hardship, we would expect proximate cities (Dallas, TX; Wichita, KS) to receive large migrant flows in the 1930s. Our maintained assumption would be that the extreme weather events in Oklahoma did not influence the labor market in Dallas except through the resulting migration.

\section{Constructing the Instruments}

We follow a two-step procedure to create the instrument for in-migration to a metropolitan area. First, we predict out-migration rates from source areas, indexed by $k$, using local economic conditions in those source areas. We use these rates to calculate a predicted outflow from each source area $k$. In the second step, we predict the probability that migrants leaving source area $k$ settle in destination $j$ based on distance alone $(k \neq j)$. The total predicted migrant flow to a destination area $j$ is then the sum of these pair-wise predictions across all possible source areas. This predicted migrant flow becomes our instrument for actual inmigration.

The out-migration rate $\left(o_{k r, 40-35}\right)$ from an area $k$ in region $r$ is determined by a vector of local economic conditions $\left(\mathrm{Z}_{k}\right)$ : 


$$
o_{k r, 40-35}=\alpha+\Phi^{\prime} Z_{k r}+\Pi_{r}+\varepsilon_{k r}
$$

$\mathrm{Z}_{k r}$ includes spending on New Deal programs and measures of extreme weather conditions. These data were collected by Price Fishback and Shawn Kantor's New Deal Project. ${ }^{17}$ We estimate the parameters of equation 2 from a single OLS regression with 117 observations, one for each sending area (69 metropolitan areas and 48 "balance of state" areas). ${ }^{18}$ The predicted flow of migrants out of area $k$ is the product of the predicted out-migration rate for area $k\left(\boldsymbol{o}_{\boldsymbol{k} r}\right.$, 40-35) from equation 2 and the population of area $k$ in 1930:

$$
\mathbf{O}_{\mathbf{k}}=\boldsymbol{o}_{\mathbf{k r}, 40-35} \cdot(\text { Population })_{k r, 30}
$$

Predicted values are written with boldface type.

In the next step, we predict the destinations of the migrants who leave source area $k$ based on the geographic distance between $k$ and all possible destinations $j$ in miles. ${ }^{19}$ In particular, for each sending area $k$ we estimate a regression of the share of people leaving area $k$ who settle in metropolitan area $j(k \neq j)$ as a function of a quadratic in the distance between areas $j$ and $k^{20}$

$$
\mathrm{P}_{\mathrm{kj}}=\alpha_{\mathrm{k}}+\theta_{\mathrm{k}}(\text { distance })_{\mathrm{kj}}+\lambda_{\mathrm{k}}\left(\text { distance }^{2}\right)_{\mathrm{kj}}+\mu_{k}
$$

The parameters in equation 4 are obtained by estimating 117 separate regressions, one for each sending area $k$. The estimates of $\theta_{\mathrm{k}}$ and $\lambda_{\mathrm{k}}$ determine the predicted probability that a migrant who leaves area $k$ will arrive in city $j$. 
The instrument for the in-migration flow to city $j$ is the sum of the predicted number of migrants who leave area $k$ that we expect to settle in city $j$ over all areas $(k \neq j)$. To avoid spatial correlation, we exclude migrants predicted to leave source areas in city $j$ 's own state.

$$
\mathbf{M}_{\mathbf{j}}=\Sigma_{\mathrm{k}=1 \ldots . \mathrm{n}(\mathrm{k} \neq \mathrm{j})}\left[\mathbf{O}_{\mathbf{k}} \cdot \mathbf{P}_{\mathbf{k j}}\right]
$$

The instrument for the in-migration rate divides the predicted flow (equation 5) by city $j$ 's population in 1930 .

The instrument for the out-migration rate from area $j$ is developed in a symmetric fashion. First, we predict the in-migration rate to each receiving area $k$ as a function of local pull factors in $k$ (note that $k$ now indexes destinations, whereas above it indexed source areas). We then convert the predicted in-migration rate into a predicted migration flow. In the next step, we use the distance between areas $j$ and $k$ to predict the share of in-migrants to area $k$ that hail from each source area $j$. Using these shares, we calculate the predicted number of outmigrants flowing from source area $j$ to destination $k$. Finally, we sum these predicted outflows across all possible destination areas $k$ and convert this flow into a predicted out-migration rate for source area $j$. This value becomes the instrumental variable for the out-migration rate for each city in the sample.

\section{Results from the Regressions Used to Construct the Instruments}

The instruments are based on the output from two sets of regressions: migration rates estimated from local push/pull factors and predicted settlement patterns based on the distance between two markets. We demonstrate here that the regression results used to build the instrument are economically intuitive and have statistical power. Table 1 presents results from 
equation 2, which predicts in- and out-migration rates using local economic conditions. Recall that the local conditions presented here are for source areas, not for destination cities whose labor market outcomes will be explained in the second stage. Because we aim to maximize the strength of the first-stage, we include only those variables that prove to be statistically significant determinants of migration rates. As a result, the two equations do not contain an identical set of explanatory variables. For those variables that are included in both models, the difference between the in- and out-migration coefficients indicates the effect on net arrivals to an area.

We find that migration flowed into cities during the Depression, but at a much lower rate than in other decades (Heim, 2000). Consistent with results reported in Fishback, Horrace, and Kantor (2006), we find that higher spending on New Deal public works projects was associated with net in-migration. Severe rain generated higher mobility rates in balance-of-state areas, though not in cities. Higher average temperatures stimulated net in-migration everywhere.

Outside major cities, a larger share of families with radios in 1930 led to a higher outmigration rate. Radio may spread information about economic opportunities outside of one's immediate area (Stromberg, 2004). Higher shares of church membership slowed out-migration rates, perhaps because church members had relatively strong community ties. Finally, the presence of manufacturing industries attracted in-migrants to non-urban areas.

Distance between cities had a large impact on migrant location choice. While we do not report the 117 sets of coefficients, the central tendency reveals that the probability that a migrant from area $k$ settled in destination $j$ is strongly related to the geographic distance between the two markets. Increasing the pair-wise distance by 1,000 miles decreases the share 
of migrants from area $k$ settling in destination $j$ by 2.8 percentage points. For all but four of the 117 source areas, the coefficients on both the linear and quadratic distance terms in equation 4 were significantly different from zero at the five percent level. The exceptions are San Diego, CA; Miami and Tampa, FL; and Norfolk, VA.

Table 2 contains the results from first-stage regressions, which relate actual net migration to predicted in- and out-migration rates. Our preferred instrument (column 2) excludes predicted migration flows from within a city's own state. This strategy reduces concerns about spatial correlation of unmeasured economic shocks. For comparison, we also show results using instruments that include all predicted migrant flows or that exclude migrants from within the city's Census region. In each case, predicted in-migration is positively related to actual net migration, while predicted out-migration is negatively related to actual net migration. The coefficients increase in size as we restrict the scope of the predicted migration to out-of-state or out-of-region arrivals, but the implied response to a one standard deviation increase in predicted migration is similar across the columns. A one standard deviation increase in the predicted in-migration rate is associated with a one standard deviation increase in actual net migration. The main results will use instruments based on out-of-state migration. For comparison, Table 5 contains results from the other two sets of instruments.

\section{The Impact of In-Migration on Local Labor Markets}

\section{A. Earnings and Wage Outcomes}

Table 3 investigates the relationship between net internal migration to a metropolitan area and five earnings and work opportunity outcomes for existing residents - annual earnings, weekly wages, weeks worked in the previous year, hourly wages, and hours worked during the 
previous week. The first column presents coefficients from an OLS specification, while the second column contains the corresponding IV results. Migrant location choices may generate an upward bias in the OLS estimation because higher wages are likely to attract migrants to an area. Indeed, in the OLS specification, net migration has a positive, but not statistically significant, relationship with weekly and hourly wages. Once we instrument for net migration rates, the coefficients in the wage regressions become negative, although they remain statistically indistinguishable from zero.

In contrast, residents of metropolitan areas that experienced high in-migration worked significantly fewer weeks over the year and, as a result, received lower annual earnings. Again, we anticipate a positive bias in the OLS coefficients for our weeks worked variable if work opportunities attracted migrants to an area during the Depression. Consistent with this expectation, the coefficients in the IV regression are substantially more negative than in the OLS regression. According to the preferred IV estimates, a one standard deviation increase in net migration would have reduced average weeks worked during the year by 0.6 of a standard deviation, leading to a small associated decline in annual earnings ( 0.2 of a standard deviation).

\section{B. Employment, Relief and Unemployment Outcomes}

Our earnings results suggest that 1930s labor markets were more likely to react to migration flows through a decline in work opportunities, rather than through reductions in wages. We next investigate whether migration affected the probability that an individual was employed, on work relief, or was idle (either fully unemployed or out of the labor force). During the Depression, employment was defined as holding a private sector or non-relief public sector job. Workers who did not hold such jobs were either idle or on emergency work relief. ${ }^{21}$ 
Emergency relief jobs were offered primarily through the Works Progress Administration (WPA). ${ }^{22}$ WPA projects operated as a partnership between the federal government and state or local governments. State or local officials proposed a series of work relief projects that ranged from maintenance in public places to building sidewalks, schools, post offices, roads, and other public infrastructure. The WPA chose among the proposed projects and provided the funding to pay workers. Individuals applied for work relief to state and local relief officials who determined their eligibility by evaluating the income of the household in comparison with a standardized budget for a household of that size and family composition. Some officials also considered length of residence in the location in determining eligibility. The typical WPA hourly earnings were about 40 to 45 percent of the hourly earnings on regular government construction projects and were designed as a supplement to enable someone without regular employment to reach a basic consumption standard while seeking work elsewhere. Work relief was supposed to be temporary employment, but there were a large number of workers who spent several years on work relief (Margo 1993; Howard 1943; Neumann, Fishback, and Kantor 2007).

Table 4 contains results from a multi-nominal logistic regression of employment and work relief on migration rates; the base category is being idle. Net in-migration to a metropolitan area does not appear to affect the probability of employment relative to the probability of being idle. However, men in metropolitan areas with high net-migration rates were far less likely to hold a relief job. A one standard deviation increase in the net migration rate is associated with a 12.5 percent ( 3.0 point) reduction in the probability of being on relief $[=\exp (8.991 \cdot 0.014)]$. This pattern suggests that migration led to a shift in the daily activities of the unemployed, but did not influence the probability of employment. 
Migrants may have been attracted to an area by the generosity of local New Deal relief programs. ${ }^{23}$ While many states restricted relief to long-term residents, qualification usually required only a single year of residency. Thus, we might expect that the coefficients in column 1 are biased upward by endogenous location decisions. In the second and third column of Table 4, we assess this possibility in the context of a linear probability model. Given that migration does not affect the probability of being employed, we focus on the probability of holding a relief job, conditional on being out of work. As expected, migration appears to have a stronger negative effect on the probability of being on relief in an IV setting. A one standard deviation increase in the net migration rate reduces the conditional probability of being on relief by 3.6 points (one-third of a standard deviation).

\section{Other Forms of Local Adjustment}

We have shown that migration to a metropolitan area reduces the work opportunities of existing residents both in terms of the number of weeks worked in the private sector and the probability of securing a relief job. Some residents might have responded to these worsening economic conditions by moving elsewhere. Table 5 considers the effect of in-migration to a metropolitan area on the probability that a member of the 1935 population had relocated by 1940. While modern evidence on this question is mixed, we find unequivocal support for the idea that in-migration to a city stimulated outflow during this period.

In OLS, in-migration to a metropolitan area has a large and statistically significant effect on the probability that an existing resident leaves the area. However, the sign of the potential bias is uncertain. For a given level of labor demand, in-migrants will be attracted to areas with recent departures, leading to an upward bias. On the other hand, a negative labor 
demand shock might simultaneously induce out-migration and repel new arrivals, generating a negative bias. Empirically, we find that the IV coefficient is slightly smaller than OLS, suggesting that, if anything, the former effect dominates.

The IV coefficient implies that a one percentage point increase in the in-migration rate to a metropolitan area increases the probability of out-migration among existing male residents by 0.75 points. We cannot interpret this probability as a displacement rate because the inmigration rate is calculated relative to the entire existing population (male and female). Assuming that men constitute half of the population in most metropolitan areas, our estimate suggests that four men would have left their 1935 residence for every ten new arrivals.

If, by shifting out the labor supply, in-migration caused wages to fall, firms in all sectors might have been attracted to the relatively cheap labor available in migrant destinations. In addition, by expanding the population, in-migration may have increased the local demand for services and other non-traded products, leading to the creation of new firms catering to the local population (for example, retail establishments). We investigate the relationship between net migration and the net creation of retail, wholesale, and manufacturing establishments in the second panel of Table 5. Our dependent variable is the change from 1935 to 1939 in the number of firms in a given sector per 1930 resident. We find no response to net in-migration in the two sectors - wholesale trade and manufacturing - that primarily serve the national market. While the relationship between migration and the number of retail stores is positive, the coefficient does not meet the conventional standards for statistical significance.

\section{Robustness Checks: Migration and Work Opportunities}


Table 6 assesses the robustness of the two economic outcomes that we find to be significantly related to net migration: weeks worked during the year for employed men and the probability of holding a relief job, conditional on being out of work. By focusing on net migration, we have implicitly assumed that in- and out-migration have equal and opposite effects on the local labor market. The first and second column of Table 6 report coefficients from regressions in which we enter both in- and out-migration separately. In-migration diminished the work opportunities of existing residents, while out-migration buoyed them. We cannot reject the hypothesis that the in-migration and out-migration coefficients are equal in absolute value for each work opportunity measure.

The main specification instruments for actual net migration with predicted out-of-state migration to mitigate the possibility of spatially correlated economic shocks. Spatial correlation could lead to a spurious negative relationship between net migration and economic outcomes if cities receive more migrants when their own economy is doing poorly (because a neighboring economy is doing worse). The third and fourth column of Table 6 present results using either predicted total migration or predicted out-of-region migration instead. All three variants produce similar coefficients.

Depression-era migrants were better educated than non-movers during the period. As a specification check, Table 7 allows the effect of in-migration to vary based on a resident's education level. In addition to the main effect of net migration, we include an interaction between a metropolitan area's net migration rate and an indicator for individuals with at least a high school degree. If migrants are more likely to compete with similarly-skilled workers, we should observe larger effects of net migration on high school graduates during this period. This should be particularly true in the non-relief sector, in which a worker's skill is more likely to 
determine his pool of competitors. The evidence corresponds to these predictions. The effect of net in-migration on the number of weeks worked during the year is twice as large for high school graduates as for non-graduates and the difference is statistically significant. On the other hand, we cannot reject that the impact of migration on the likelihood of holding a relief job is the same for graduates and non-graduates.

\section{E. Magnitudes in the Context of the Dust Bowl Migration}

The largest migration of the Depression era was the flight from the dust storms that decimated agricultural production in the southern Great Plains (Hansen and Libecap, 2004; Cunfer 2005). Many of the former residents of the Dust Bowl areas settled in California. As an illustration of the magnitude of our estimates, we use our coefficients to assess the impact of this migration on California's economy.

While collectively - and pejoratively - referred to as "Okies," the Dust Bowl migrants hailed not only from Oklahoma but also from Texas, Arkansas and Missouri. Gregory (1989) reports that 315,000 individuals from these four states settled in California between 1930 and 1940 , compared to 243,000 in the previous decade. A conservative estimate would place the number of additional migrants contributed by the Dust Bowl at 72,000 for the period 1930 to

1940, 51 percent of whom were male. ${ }^{24}$ We consider the flow of 37,000 new men into the state, which represented a 1.8 percent increase in the state's population.

How did this influx affect California's one million existing male residents? Our results suggest that, to begin with, a number of male residents who lived in California in 1935 would have left the state. An in-migration of this size would have encouraged 1.3 percent $(=0.745$. 0.018 in-migration rate; see Table 5 , row 1 for 0.745 coefficient estimate) of the state's existing 
male population, or 13,000 Californians, to relocate elsewhere. The resulting out-migration would have reduced California's net migration burden to 24,000 arrivals, the equivalent of 1.2 percent of the population.

In-migrants would also have crowded the queue for relief jobs. Absent the Dust Bowl migration, 220,000 men in California would have been out-of-work (=1 million men $\cdot 0.22$ share out of work). The Dust Bowl migration would have reduced the share of out-of-work men holding a relief job by 3.1 percentage points $(=-2.583 \cdot 0.012$ net migration rate; see Table 4 , row 3 for -2.583 estimate). This crowding-out would have reduced the number of men on relief by $6,800(=220,000$ out of work men $\cdot 0.031$ share estimated to lose relief work).

In addition, for some employed men, competition from new migrants would have reduced work opportunities. If the estimated effect of migration on weeks worked was spread broadly through the population, the average employed man would have lost only a half-week of work during the year $(=-0.996 \cdot 0.012$ net migration rate $\cdot 45.7$ average weeks worked per year; see Table 3, row 4 for -0.996 coefficient estimate). However, empirically, the effect of migration is concentrated among men in the bottom decile of the weeks-of-work distribution. Men at the tenth percentile of this distribution worked 26 weeks during the year, a level that may indicate in-voluntary part-year employment (job sharing). We define an indicator variable equal to one for men who worked 26 or fewer weeks during the year. An IV regression of this indicator on the net migration rate produces a coefficient of 0.496 (s.e. $=0.180)$. Absent the Dust Bowl migration, 88,000 male Californians, or 11.3 percent of employed men, would have been working part-year. In-migration would have increased this share to 11.9 percent $(=0.496$. 0.012 net migration rate), resulting in an additional 4,800 men engaged in job sharing. 
Our estimates imply that the 37,000 male Dust Bowl migrants would have caused substantial economic change for a total of 24,600 California men: 13,000 men encouraged to leave the state, 6,800 men crowded out of relief work, and an additional 4,800 men working part-year. In other words, for every ten Dust Bowl migrants arriving in California, nearly seven male residents would have experienced some form of economic displacement.

\section{Conclusion}

Throughout American history there has been extensive debate about the impact of immigrants on the economic status of native-born workers. The conversation has become particularly heated recently as the nation considers immigration reform. Economists working with modern data have not reached a consensus about the impact of immigrants on wages and employment.

During the Depression and strict immigration quotas, immigration from abroad slowed to a halt during the 1930s. Even so, residents in areas where the Depression was less severe protested the arrival of migrants from other, less fortunate regions. The new arrivals were accused of taking jobs, lowering wages, and crowding relief rolls. Using aggregate data on internal migration flows matched to individual records from the 1940 Census, we examine the impact of net migration on the economic welfare of workers along a variety of dimensions.

As is often the case in the modern literature, we find that the impact of in-migration on hourly earnings in the 1930s was small and not statistically significant. However, in-migrants threatened the economic prospects of longer-term residents in other ways. During a decade in which unemployment rates hovered above ten percent and many workers were unable to find full-time jobs, work opportunities and access to work relief were highly sought after. Residents 
of metropolitan areas that experienced high in-migration during the Depression decade worked fewer weeks during the year. Although the probability of obtaining a regular employment did not fall, those who were out of work faced greater difficulty in securing a work relief position. Finally, as has been found in the modern era, greater in-migration stimulated out-migration by longer-term residents.

Our findings suggest that localized protests against in-migration could still occur today even if our borders were completely sealed. What opponents of immigration often fail to realize is that disparities in labor markets across geographic areas encourage people to migrate internally, thus affecting labor market outcomes. While the vehemence of protest might be dampened if newcomers resembled long-standing residents in terms of race, ethnicity, and citizenship, the economic impact of this migration may still generate opposition. 


\section{Bibliography}

Altonji, Joseph G. and David Card. 1991. "The Effects of Immigration on the Labor Market Outcomes of Less-skilled Natives." In Immigration, Trade and the Labor Market, ed. J. Abowd and R. Freeman. Chicago: University of Chicago Press.

Bernanke, Ben S. 1986. "Employment, Hours, and Earnings in the Depression: An Analysis of Eight Manufacturing Industries." American Economic Review, 76(1): 82-107.

Blanchard, Olivier and Lawrence Katz. 1992. "Regional Evolutions." Brookings Papers on Economic Activity, 1: 1-75.

Borjas, George J. 2001. "Does Immigration Grease the Wheels of the Labor Market?" Brookings Papers on Economic Activity: 69-119.

Borjas, George J. 2003. "The Labor Demand Curve Is Downward Sloping: Reexamining the Impact of Immigration on the Labor Market." Quarterly Journal of Economics, XX: 13351374.

Borjas, George J. 2006. "Native Internal Migration and the Labor Market Impact of Immigration." Journal of Human Resources, 41(2): 221-258.

Borjas, George J., Richard B. Freeman, and Lawrence F. Katz. 1997. "How Much Do Immigration and Trade Affect Labor Market Outcomes?" Brookings Papers on Economic Activity: 1-67.

Boustan, Leah Platt. 2007. "Was Postwar Suburbanization 'White Flight'? Evidence from the Black Migration.” NBER Working Paper 13543.

Card, David. 2001. "Immigrant Inflows, Native Outflows, and the Local Market Impacts of Higher Immigration." Journal of Labor Economics, 19(1): 22-64.

Carter, Susan and Richard Sutch. 1999. "Historical Perspectives on the Economic Consequences of Immigration into the United States." In The Handbook of International Migration: The American Experience, ed. Charles Hirschman, Philip Kasinitz, and Joshua DeWind, 319-341. New York: Russell Sage Foundation.

Cunfer, Geoffrey. 2005. On the Great Plains: Agriculture and Environment. Texas A\&M University Press.

Federal Emergency Relief Administration. 1934. Unemployment Relief Census, October 1933. Washington D.C.: Government Printing Office.

Ferrie, Joseph. 1996. "The Impact of Immigration on Natives in the Antebellum U.S., 185060." Northwestern University Center for Urban Affairs and Policy Research Working Paper. 
Fishback, Price, William Horrace and Shawn Kantor. 2006. "The Impact of New Deal Expenditures on Mobility During the Great Depression." Explorations in Economic History, 43(2): 179-222.

Fishback, Price, Michael Haines, and Shawn Kantor. 2001. "The Impact of the New Deal on Black and White Infant Mortality in the South.” Explorations in Economic History, 38: 93-122.

Fishback, Price, Michael Haines, and Shawn Kantor. 2007. "Births, Deaths, and New Deal Relief During the Great Depression." Review of Economics and Statistics, 89: 1-14.

Filer, Randall. 1992. "The Effect of Immigrant Arrivals on Migratory Patterns of Native Workers." In Immigration and the Workforce: Economic Consequences for the United States and Source Areas, ed. George J. Borjas and Richard B. Freeman. Chicago: University of Chicago Press.

Frey, William H. 1995. "Immigration and Internal Migration "Flight' from U.S. Metro Areas: Towards a New Demographic Balkanization.” Urban Studies 32(4-5): 733-57.

Frey, William H. Kao-Lee Liaw, Yu Xie, and Marcia J. Carlson. 1996. "Interstate Migration of the U.S. Poverty Population: Immigration 'Pushes' and Welfare Magnet 'Pulls'." Population and Environment, 17(6): 491-533.

Friedberg, Rachel M and Jennifer Hunt. 1995. "The Impact of Immigrants on Host Country Wages, Employment and Growth.” Journal of Economic Perspectives, 9(2): 23-44.

Gardner, John, and William Cohen. 1992. "Demographic Characteristics of the Population of the United States, 1930-1950: County-Level.” Inter-university Consortium for Political and Social Research Data File 0020.

Goldin, Claudia. 1994. "The Political Economy of Immigration Restriction in the United States, 1890 to 1921." In The Regulated Economy, ed. Claudia Goldin and Gary Libecap, 223-58. Chicago: University of Chicago Press.

Gregory, James N. 1989. American Exodus: The Dustbowl Migration and Okie Culture in California. New York: Oxford University Press.

Hanes, Christopher L. 1996. "Changes in the Cyclical Behavior of Real Wage Rates, 18701990.” Journal of Economic History, 56: 837-861.

Haines, Michael. 2004. "Historical, Demographic, Economic, and Social Data: The United States, 1790-2000." Inter-university Consortium for Political and Social Research Data Set 2896.

Hansen, Zeynep and Gary Libecap. 2004. "Small Farms, Externalities and the Dust Bowl of the 1930s.” Journal of Political Economy, 112(3): 665-694. 
Hatton, Timothy and Jeffrey Williamson. 1995. "The Impact of Immigration on American Labor Markets Prior to the Quotas," National Bureau of Economic Research Working Paper No. 5185.

Heim, Carol. 2000. "Structural Changes: Regional and Urban." In Cambridge Economic History of the United States, ed. Stanley Engerman and Robert Gallman, 93-190. Cambridge: Cambridge University Press.

Howard, Donald S. 1943. The WPA and Federal Relief Policy, Russell Sage: New York.

Kritz, Mary M. and Douglas T. Gurak. 2001. "The Impact of Immigration on the Internal Migration of Natives and Immigrants." Demography, 38(1): 133-45.

Levy, Mildred B. and Walter J. Wadycki. 1974. "What Is the Opportunity Cost of Moving? Reconsideration of the Effects of Distance on Migration." Economic Development and Cultural Change. 22(2): 198-214.

Lewis, Ethan. 2004. "How Did the Miami Labor Market Absorb the Mariel Immigrants?" Federal Reserve Bank of Philadelphia Working Paper 04-03.

Lewis, Ethan. 2003. "Local, Open Economies Within the US: How Do Industries Respond to Immigration?” Federal Reserve Bank of Philadelphia Working Paper 04-01.

Margo, Robert A. 1993. "Employment and Unemployment in the 1930s." Journal of Economic Perspectives, 7(2): 41-59.

Moulton, Harold G. 1936. "In Defense of the Longer Work Week," Annals of the American Academy of Political and Social Science, 184: 68-71.

Neumann, Todd, Price Fishback, and Shawn Kantor. 2007. "The Dynamics of Relief Spending and the Private Urban Labor Market During the New Deal." National Bureau of Economic Research Working Paper No. 13692, December.

Ottaviano, Gianmarco and Giovanni Peri. 2006. "Rethinking the Effects of Immigration on Wages.” NBER Working Paper No. 12497.

Ruggles, Steven and Matthew Sobek et al. 2003. Integrated Public Use Microdata Series: Version 3.0 . http://www.ipums.org.

Rosenbloom, Joshua L. and William A. Sundstrom. 2004. "The Decline and Rise of Interstate Migration in the United States. Evidence from the IPUMS, 1850-1990." Research in Economic History, 22: 289-325.

Rosenbloom, Joshua L. and William A. Sundstrom. 1999. “The Sources of Regional Variation in the Severity of the Great Depression: Evidence from US Manufacturing, 1919-1937."

Journal of Economic History, 59(3): 714-747. 
Schwartz, Aba. 1973. "Interpreting the Effect of Distance on Migration." Journal of Political Economy, 81(5): 1153-1169.

Sjaastad, Larry A. 1962. "The Costs and Returns of Human Migration.” Journal of Political Economy. 70: 80-93.

Steinbeck, John. 1939. The Grapes of Wrath. New York: The Viking Press.

Strömberg, David. 2004. "Radio's Impact on Public Spending.” Quarterly Journal of Economics, 119(1): 189-221.

U.S. Bureau of the Census. 1940. Census of Agriculture: State Data. Washington, DC: Government Printing Office.

U.S. Bureau of the Census. 1933. Fifteenth Census of the United States: 1930, Families. Volume 6. Washington, DC: Government Printing Office.

U.S. Bureau of the Census.1943. Sixteenth Census of the United States:1940, Population, Internal Migration 1935 to 1940. Washington, DC: Government Printing Office.

U.S. Bureau of Foreign and Domestic Commerce. 1939. Consumer Data Handbook, 1939 Edition.. Washington, D.C.: Government Printing Office.

U.S. Office of Government Reports. 1940. "County Reports of Estimated Federal Expenditures March 41933 - June 30, 1939. Statistical Section, Report No. 10, vol. 1.” Washington, D.C.: Government Printing Office.

U.S. Census of Partial Employment, Unemployment and Occupation. 1938. Final Report on Total and Partial Unemployment. Washington, DC: Government Printing Office.

Walker, L.C. 1993. "The Share-the-Work Movement." Annals of the American Academy of Political and Social Science, 165: 13-19.

Wallis, John Joseph. 1989. "Employment in the Great Depression: New Data and Hypotheses." Explorations in Economic History, 26(1): 45-72.

White, Michael J. and Zai Liang. 1998. "The Effect of Immigration on the Internal Migration of the Native-Born Population, 1981-1990." Population Research and Policy Review, 17(2): 141-166.

Wright, Richard, Mark Ellis and Michael Reibel. 1997. "The Linkage between Immigration and Internal Migration in Large Metropolitan Areas in the United States." Economic Geography, 73(2): 232-252. 


\section{Figure 1a}

\section{In-Migration Rates and Earnings Growth for Manufacturing Workers by Metropolitan Area, 1935-1940}

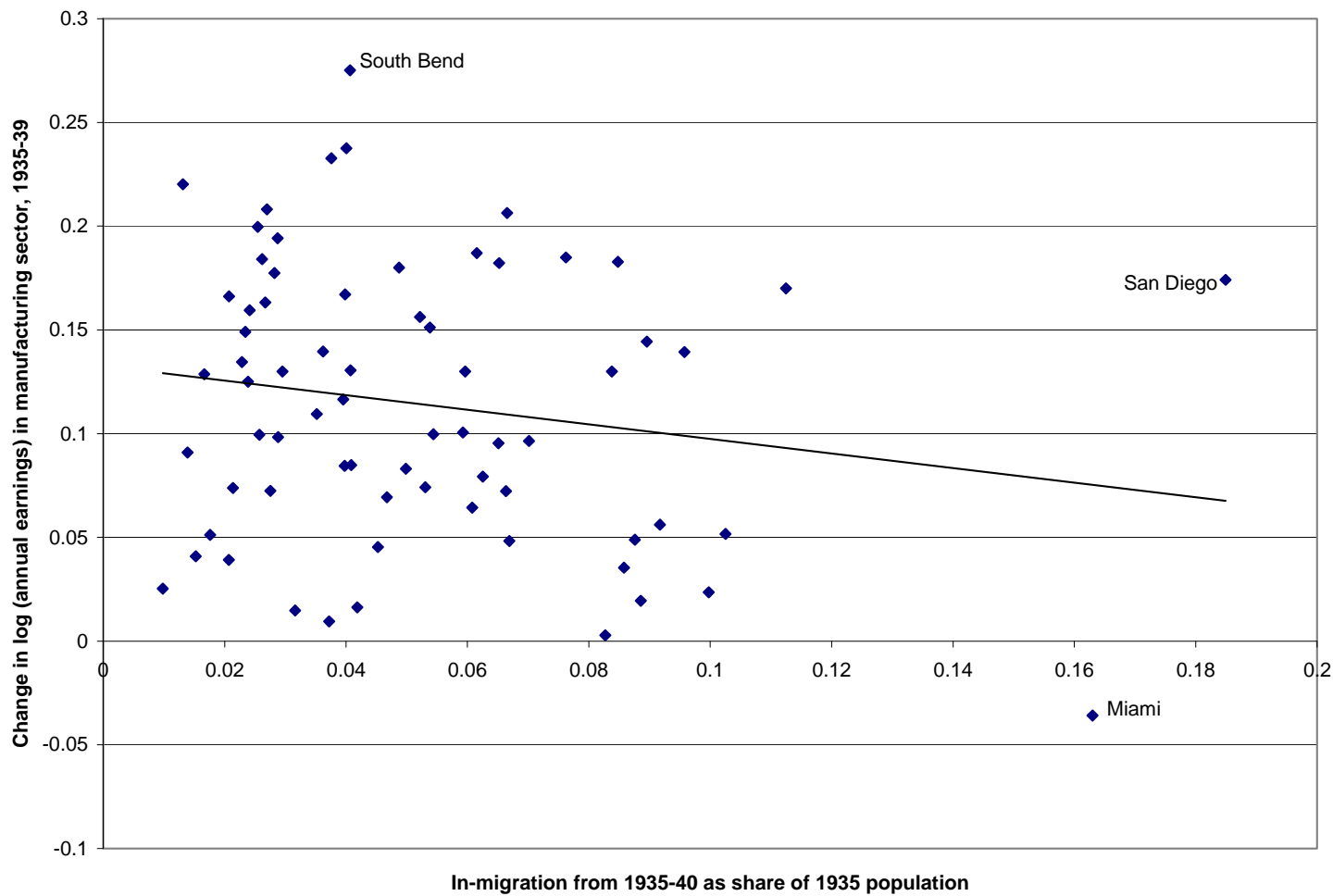

Notes: Each dot represents one of the 69 metropolitan areas with complete data in the sample. The average annual earnings for wholesale, retail, and manufacturing workers in 1935 are constructed from data on the total wage bill and the count of wage earners from US Bureau of Foreign and Domestic Commerce (1939). The 1939 earnings data were taken from Michael Haines' compilation of county, city, and state level data sets in ICPSR 2896 on Historical, Demographic, Economic, and Social Data: The United States, 1790-2000. The numbers of male migrants can be found in the 1940 Census volume on internal migration (U.S. Bureau of the Census, 1943). 


\section{Figure 1b}

In-Migration Rates and Earnings Growth for Retail Workers by Metropolitan Area, 1935-1940

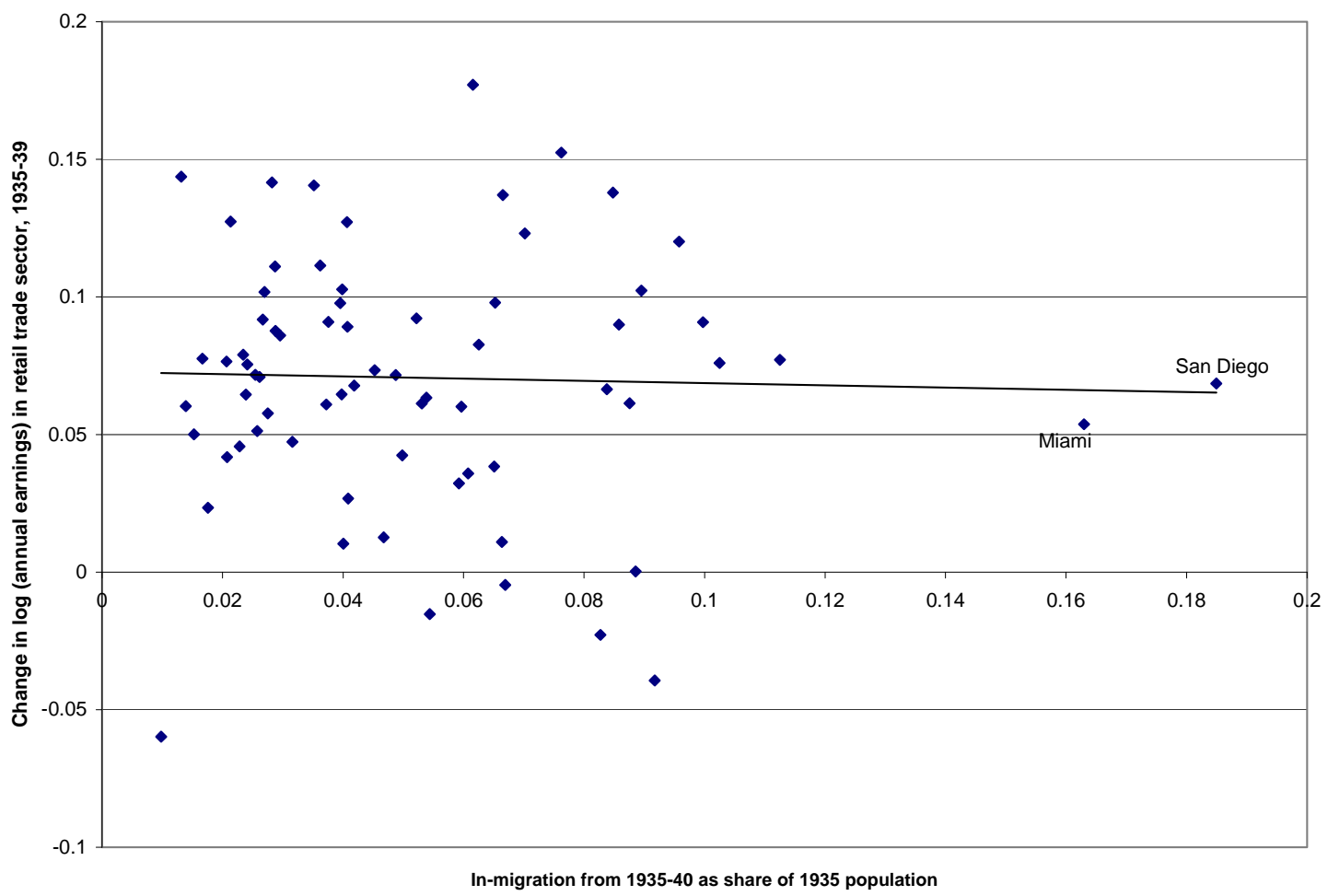


Figure 1c

In-Migration Rates and Earnings Growth for Wholesale Workers by Metropolitan Area, 1935-1940

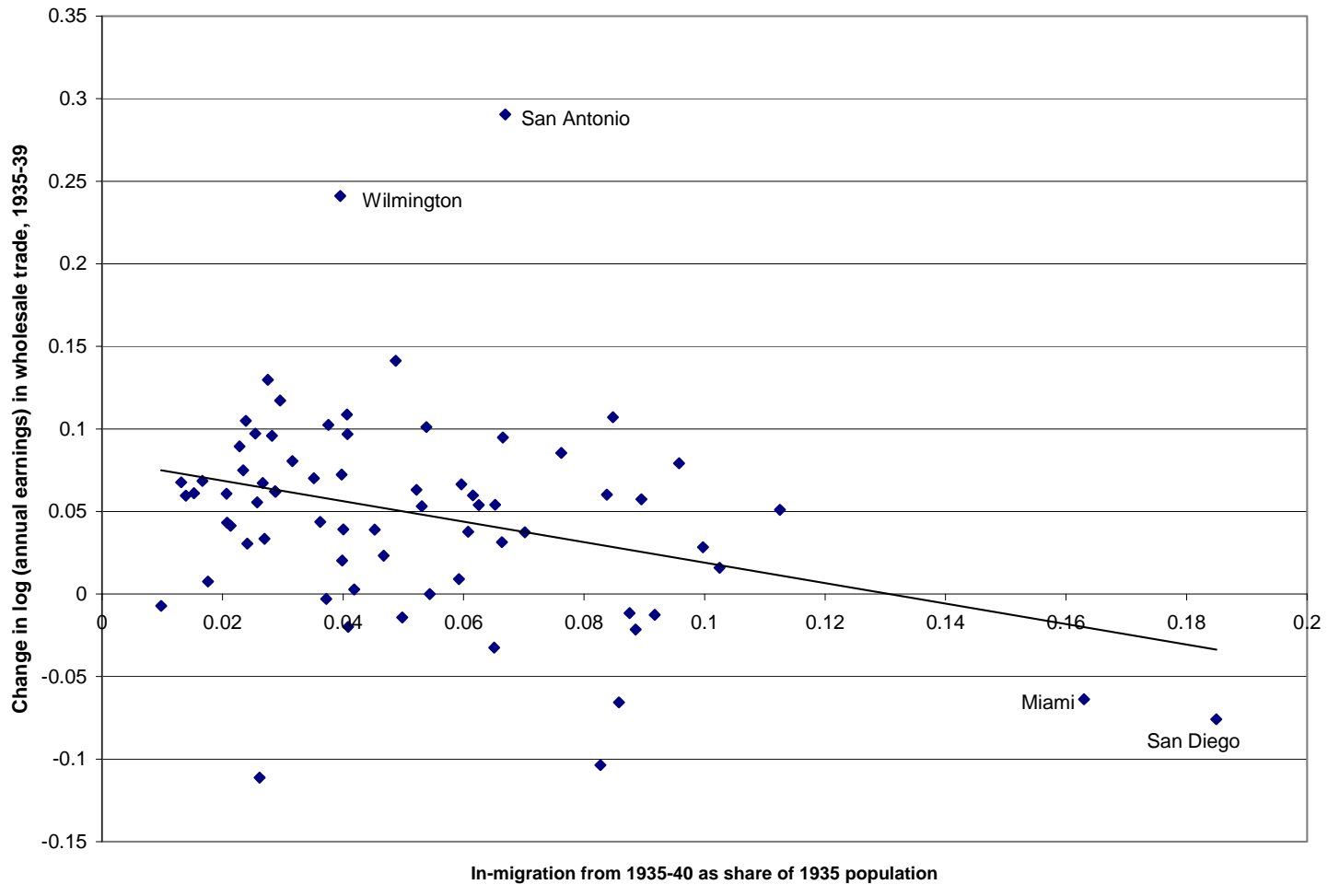




\section{Table 1}

Determinants of male in- and out-migration: 69 metropolitan areas and 48 balance of state areas, 1935-40

\begin{tabular}{|c|c|c|}
\hline \multirow[b]{2}{*}{ RHS variables } & \multicolumn{2}{|c|}{ Dependent variable } \\
\hline & In-migration rate & Out-migration rate \\
\hline$=1$ if central city & $\begin{array}{c}0.032 \\
(0.021)\end{array}$ & $\begin{array}{c}0.025 \\
(0.020)\end{array}$ \\
\hline $\begin{array}{l}\text { New Deal \$ per cap, in } \$ 100 \text { s } \\
\text { Public works, 1933-39 }\end{array}$ & $\begin{array}{c}0.046 \\
(0.012)\end{array}$ & $\begin{array}{c}0.014 \\
(0.008)\end{array}$ \\
\hline $\begin{array}{l}\text { Weather } \\
\text { Months of Severe or Extreme } \\
\text { Wetness, 1935-39 }\end{array}$ & $\begin{array}{c}0.016 \\
(0.002)\end{array}$ & $\begin{array}{c}0.004 \\
(0.002)\end{array}$ \\
\hline Wet months $\cdot=1$ if city & $\begin{array}{l}-0.016 \\
(0.003)\end{array}$ & $\begin{array}{l}-0.007 \\
(0.002)\end{array}$ \\
\hline Average temperature, $1935-39$ & $\begin{array}{c}0.005 \\
(0.001)\end{array}$ & $\begin{array}{c}0.003 \\
(0.001)\end{array}$ \\
\hline Other conditions & & \\
\hline Share families with radio, 1930 & --- & $\begin{array}{c}0.178 \\
(0.048)\end{array}$ \\
\hline Share with radio $\cdot=1$ if city & --- & $\begin{array}{l}-0.160 \\
(0.045)\end{array}$ \\
\hline $\begin{array}{l}\text { Church membership in } 1926 \text { as } \\
\text { share of } 1930 \text { population }\end{array}$ & --- & $\begin{array}{l}-0.065 \\
(0.022)\end{array}$ \\
\hline Manuf. employ per cap, 1929 & $\begin{array}{c}0.945 \\
(0.312)\end{array}$ & --- \\
\hline Manuf. employ $\cdot=1$ if city & $\begin{array}{l}-1.068 \\
(0.283)\end{array}$ & --- \\
\hline $\begin{array}{l}\text { Region dummies? } \\
\mathrm{N}\end{array}$ & $\begin{array}{c}\mathrm{Y} \\
117\end{array}$ & $\begin{array}{c}Y \\
117\end{array}$ \\
\hline
\end{tabular}

Notes: Standard errors are in parentheses and are clustered by state. Observations include 69 metropolitan areas and 48 balance of state areas.

Sources: The number of male migrants are from the 1940 Census volume on internal migration (U.S. Bureau of the Census, 1943). New Deal spending information on public works is from the U.S. Office of Government Reports (1940). The share of families with radios is from the 1930 Census volume on Families (1933). Church membership data are from the U.S. Bureau of Census, Census of Religious Bodies, 1926. The number of 
manufacturing workers was reported in the 1929 Census of Manufacturing. Per capita adjustments are based on the 1930 population. The public works data was collected by Price Fishback and Shawn Kantor. The full New Deal dataset can be found on Price Fishback's website at the University of Arizona

(http://econ.arizona.edu/faculty/Fishback.aspx). All other socio-economic variables were taken from Michael Haines' compilation of county, city, and state level data sets in ICPSR 2896 on Historical, Demographic,

Economic, and Social Data: The United States, 1790-2000. The climate information is available from the National Climatic Data Center (NCDR). Text files of the data were accessed from ftp://ftp.ncdc.noaa.gov/pub/data/cirs/ (August 2003). 
Table 2

First-stage regressions:

Relationship between predicted and actual migration, Men 1935-40

Dependent variable $=$ Net number of migrants between 1935 and 40 as a percentage of 1935 population

\begin{tabular}{l|ccc}
\hline & \multicolumn{3}{|c}{ Assigned migrant flows } \\
& All & Out of state & Out of region \\
\hline Predicted in-mig. rate & 2.589 & 5.632 & 8.352 \\
& $(0.317)$ & $(0.739)$ & $(1.173)$ \\
Predicted out-mig. rate & -2.879 & -4.400 & -7.392 \\
& $(0.450)$ & $(0.537)$ & $(1.753)$ \\
N & 131,006 & & \\
Metropolitan areas & 69 & 131,006 & 131,006 \\
F-statistic & 35.68 & 69 & 69 \\
\hline
\end{tabular}

Notes: Regressions are estimated at the individual level using data from the 1940 IPUMS and are weighted by the inverse of the number of observations in the metropolitan area. Standard errors are in parentheses and are clustered by metropolitan area. Regressions include region dummies and full set of controls from the second stage. See Table 3 notes for complete list of city-level and individual controls. 
Table 3

The effect of net migration on earnings, wages, and work time in 1940

Coefficients on net number of migrants between 1935 and 40 as a percentage of 1935 population

\begin{tabular}{l|cc}
\hline Dependent variable & OLS & IV \\
\hline $\ln ($ annual earnings) & -0.218 & -1.004 \\
Wages & $(0.578)$ & $(0.615)$ \\
$\ln ($ weekly wage) & 0.561 & -0.007 \\
& $(0.379)$ & $(0.547)$ \\
$\ln$ (hourly wage) & 0.471 & -0.478 \\
& $(0.545)$ & $(0.746)$ \\
Work opportunities & & \\
$\ln ($ weeks worked) & -0.779 & -0.996 \\
& $(0.325)$ & $(0.306)$ \\
$\ln ($ hours worked) & 0.089 & 0.471 \\
& $(0.267)$ & $(0.301)$ \\
$\mathrm{N}$ & & 96,070 \\
\hline
\end{tabular}

Notes: Regressions are estimated at the individual level using data from the 1940 IPUMS and are weighted by the inverse of the number of observations in the metropolitan area. Standard errors are in parentheses and are clustered by metropolitan area. The sample includes only men employed during the Census week who report positive earnings. The weekly wage is annual earnings in 1939 divided by weeks worked in 1939. The hourly wage is the weekly wage divided by the hours worked in the week prior to the Census survey in March 1940. Individual controls include an indicator for being non-white, a cubic polynomial in age, and a dummy for each year of completed school. The instruments are described in section IV.C of the text.

Sources: The county-level aggregates for the age distribution and share of the population that is black, foreignborn, or illiterate in 1930 were constructed using the New Deal datasets compiled by Price Fishback and Shawn Kantor. These are matched to the metropolitan areas in the sample. The age distribution information came from Gardner and Cohen, 1992. The shares black, foreign born, and illiterate in 1930 are from the 1930 population census and can be found in Michael Haines' compilation of county, city, and state level data sets in ICPSR 2896 on Historical, Demographic, Economic, and Social Data: The United States, 1790-2000. The average annual earnings for wholesale, retail, and manufacturing workers in 1935 are constructed from data on wages paid and wage earners from US Bureau of Foreign and Domestic Commerce (1935). The relief and unemployment sources are respectively, Federal Emergency Relief Administration (1934) and U.S. Census of Partial Employment (1938). The 1937 information is also available in the 1940 Census files from Haines in ICPSR 2896. 


\section{Table 4}

\section{The effect of net migration on employment and work relief}

Coefficients on net number of migrants between 1935 and 40 as a percentage of 1935 population

\begin{tabular}{l|ccc}
\hline Dependent variable & MNL & OLS & IV \\
\hline$=1$ if employed & 1.839 & --- & \\
& $(1.177)$ & & -- \\
$=1$ if on work relief & -8.991 & --- & \\
& $(2.829)$ & & -2.583 \\
$=1$ if on work relief conditional on & --- & -1.695 & $(0.854)$ \\
being out of work & & $(0.505)$ & 29,121 \\
$\mathrm{~N}$ & 131,006 & 29,121 & \\
\hline
\end{tabular}

Notes: Column 1 contains results from a multi-nominal logistic regression that contains all men who meet the sample criteria. The base category is being idle. Columns 2 and 3 include only those men who are currently unemployed or out of the labor force. Regressions are estimated at the individual level using data from the 1940 IPUMS and are weighted by the inverse of the number of observations in the metropolitan area. Standard errors are in parentheses and are clustered by metropolitan area. See the notes to Table 3 for the set of individual- and city-level control variables and their sources. The instruments are described in section IV.C of the text. 
Table 5

Other labor market adjustments: The out-migration of existing workers and the creation of new establishments, 1935-1940

\begin{tabular}{l|cc}
\hline Dependent variable & OLS & IV \\
\hline $\begin{array}{l}\text { Out migration } \\
=1 \text { if left SMSA, 1935-40 }\end{array}$ & 0.880 & 0.745 \\
& $(0.276)$ & $(0.322)$ \\
$\mathrm{N}$ & 142,327 & 142,327 \\
Establishment creation & & \\
$\begin{array}{l}\text { Change from 1935-39 } \\
\text { \# retail est. per 1000 }\end{array}$ & 12.892 & \\
& $(8.585)$ & 11.243 \\
\# wholesale est. per 1000 & 1.128 & $(9.051)$ \\
& $(1.158)$ & 0.874 \\
\# manufacturing est. per 1000 & -0.151 & $(1.493)$ \\
& $(1.204)$ & 0.979 \\
$\mathrm{~N}$ & 69 & $(1.867)$ \\
\hline
\end{tabular}

Notes: Reported coefficients for the gross number of in-migrants (row 1) or net number of migrants (row 2-4) between 1935 and 1940 as a percentage of 1935 population. Standard errors are in parentheses and are clustered by metropolitan area. Regressions in the first row are estimated at the individual level and weighted by the inverse of the number of observations in the metropolitan area. Regressions in rows 2-4 are estimated at the city level. Controls in the city-level regressions include region dummies, the age distribution, and the share of the population that was black, foreign-born or illiterate in 1930. The instruments are described in section IV.C of the text. Sources: The information on establishments in 1935 is reported in U.S. Bureau of Foreign and Domestic Commerce (1935). The information on establishments in 1939 are from the 1940 Census and can be found in Michael Haines' compilation of county, city, and state level data sets in ICPSR 2896 on Historical, Demographic, Economic, and Social Data: The United States, 1790-2000. 


\section{Table 6}

\section{Robustness checks: The relationship between migration and work opportunities}

\begin{tabular}{l|cccc}
\multicolumn{4}{c}{ Coefficients on net number of migrants between 1935 and 40 as a percentage of 1935 population } \\
\hline & \multicolumn{2}{|c}{ Out of state } & All & Out of region \\
Dependent variable & In migration & Out migration & Net mig. & Net mig. \\
\hline =1 if on work relief, conditional & -2.558 & 1.768 & -2.475 & -2.826 \\
on being out of work & $(0.834)$ & $(1.139)$ & $(0.979)$ & $(0.919)$ \\
& & & & \\
$\ln$ (weeks worked) & -0.996 & 1.136 & -0.731 & -1.099 \\
& $(0.313)$ & $(0.624)$ & $(0.329)$ & $(0.344)$ \\
\hline
\end{tabular}

Notes: Standard errors are in parentheses and are clustered by metropolitan area. Regressions are estimated at the individual level and weighted by the inverse of the number of observations in the metropolitan area. The first row includes men who are currently out of work $(29,121)$, while the second row contains men who were employed in the Census week $(96,070)$. See the notes to Tables 3 and 4 for a list of the individual- and city-level control variables and a discussion of the samples underlying each regression. 
Table 7

The effect of net migration on work opportunities by education level

\begin{tabular}{|c|c|c|}
\hline \multirow[b]{2}{*}{ RHS variables } & \multicolumn{2}{|c|}{ Dependent variable } \\
\hline & $\begin{aligned}= & 1 \text { if on work relief } \\
& \text { (if out of work) }\end{aligned}$ & $\ln ($ weeks worked) \\
\hline Net migration & $\begin{array}{l}-2.352 \\
(0.888)\end{array}$ & $\begin{array}{l}-0.661 \\
(0.289)\end{array}$ \\
\hline Net migration $\cdot$ High school graduate & $\begin{array}{l}-0.619 \\
(0.827)\end{array}$ & $\begin{array}{l}-0.642 \\
(0.333)\end{array}$ \\
\hline
\end{tabular}

Notes: Standard errors are in parentheses and are clustered by metropolitan area. Regressions are estimated at the individual level and weighted by the inverse of the number of observations in the metropolitan area. See the notes to Tables 3 and 4 for a list of the individual- and city-level control variables and a discussion of the samples underlying each regression. The set of completed schooling dummy variables absorb the main effect of being a high school graduate. 
Appendix Table 1:

Summary statistics at the metropolitan area level

\begin{tabular}{|c|c|c|}
\hline Variable & Mean & Standard Deviation \\
\hline $\begin{array}{l}\text { Dependent Variables } \\
\text { Wages } \\
\text { Annual earnings, } \$ 2000\end{array}$ & $\$ 16,215$ & $\$ 1924.12$ \\
\hline Weekly wage, $\$ 2000$ & $\$ 391.22$ & $\$ 71.99$ \\
\hline Weeks worked & 45.76 & 1.55 \\
\hline Hourly wage, $\$ 2000$ & $\$ 10.10$ & $\$ 2.39$ \\
\hline Hours worked & 43.52 & 2.18 \\
\hline $\begin{array}{l}\text { Employment } \\
=1 \text { if idle } \\
\text { (unemployed or OLF) }\end{array}$ & 0.164 & 0.036 \\
\hline$=1$ if on work relief & 0.056 & 0.027 \\
\hline $\begin{array}{l}=1 \text { if on work relief } \\
\text { (conditional on being out of work) }\end{array}$ & 0.248 & 0.098 \\
\hline$=1$ if left SMSA, 1935-40 & 0.102 & 0.049 \\
\hline $\begin{array}{l}\text { Establishment creation } \\
\text { \# establishments per } 1000 \text { people, } \\
\text { Level } 1935 \\
\text { - Retail }\end{array}$ & 10.56 & 2.47 \\
\hline - Wholesale & 1.56 & 0.622 \\
\hline - Manufacturing & 1.28 & 0.480 \\
\hline $\begin{array}{l}\text { Explanatory Variables } \\
\text { In-migration rate, 1935-40 }\end{array}$ & 0.053 & 0.033 \\
\hline Out-migration rate, $1935-40$ & 0.067 & 0.027 \\
\hline Net migration rate, $1935-40$ & -0.014 & 0.021 \\
\hline
\end{tabular}




\begin{tabular}{lcc}
\hline Appendix Table 1, continued & & \\
\hline $\begin{array}{l}\text { Instruments } \\
\text { Predicted in-migration rate, all }\end{array}$ & 0.014 & 0.010 \\
Predicted out-migration rate, all & 0.015 & 0.007 \\
$\begin{array}{l}\text { Pred. in-mig. rate, out of state } \\
\text { Pred. out-mig. rate, out of state }\end{array}$ & 0.005 & 0.004 \\
Pred. in-mig. rate, out of region & 0.006 & 0.004 \\
Pred. out-mig. rate, out of region & 0.003 & 0.002 \\
\hline
\end{tabular}

Note: Individual-level wage and employment information presented as metropolitan area averages. Each row has 69 observations. 


\section{ENDNOTES}

${ }^{1}$ The California Indigent Act of 1933 made it a crime to bring anyone likely to become a public charge into the state. While the law was rarely enforced, it was used to prosecute some Dust Bowl migrants who helped their relatives enter the state until it was invalidated by the Supreme Court in 1941 (Edwards v. California). Californians also tried to scare possible migrants away from the state. For example, one billboard in Oklahoma carried the message: "NO JOBS in California/If YOU are looking for work - KEEP OUT/6 men for every job/No state relief available for non-residents." For more on the politics of migration control in California, see Gregory (1989).

${ }^{2}$ For contemporary policy statements on job sharing, see Walker (1933) and Moulton

${ }^{3}$ See Boustan (2007) for use of a similar method to examine the impact of black inmigration into the North on white flight to the suburbs.

${ }^{4}$ Hatton and Williamson (1995) use a national time series of immigrant arrivals to estimate the impact of immigration on native wages. Carter and Sutch (1999) survey the historical literature. See also Ferrie (1996).

${ }^{5}$ Borjas (2006) demonstrates that state-based estimates are only half as large as their national equivalents; metropolitan area estimates are even smaller. Between 40 and 60 percent of this reduction is due to native out-migration.

${ }^{6}$ Exceptions include Frey (1995), Frey, et al. (1996), and White and Liang (1998).

${ }^{7}$ Our analysis includes only internal migrants. Foreign arrivals constituted only two percent of cross-county moves. We have estimated models that include foreign arrivals; not surprisingly, the results do not qualitatively change.

${ }^{8}$ We aggregate data from the following cities: Boston, Cambridge, Lowell, Somerville, MA; Camden, NJ and Philadelphia, PA; Elizabeth and Newark, NJ; Fall River, MA, New Bedford, MA and Providence, RI; Fort Worth and Dallas, TX; Kansas City, MO and Kansas City, KS; Los Angeles and Long Beach, CA; Yonkers and New York City, NY; Oakland and San Francisco, CA; and St. Paul and Minneapolis, MN. Sacramento, CA and Charlotte, NC are missing migration data, and Washington, DC and Flint, MI are missing Census of Manufacturing earnings data in 1935. While we use the SMA concept to guide our aggregation decisions, our data captures only those migrants who settle in the central cities of these areas, rather than the surrounding suburban counties. In fact, some individuals who are classified as in-migrants from the balance of a city's own state might have moved to the city from the suburban ring, thus having no net effect on local labor supply. Mis-measurement of this type will attenuate our OLS estimates, providing an additional motivation for our instrumental variables analysis.

${ }^{9}$ The Census collected detailed information on wages and salaries only, and not on selfemployment income in 1940.

${ }^{10}$ Following Goldin and Margo (1992), we replace top-coded incomes with 1.4 times the top-code.

${ }^{11}$ Migrants were, on average, three years younger than men who remained in the same county between 1935 and 1940 (31.2 versus 34.0 years of age), but had completed two more years of education ( 9.4 versus 7.2 years of schooling). Migrants were also twice as likely to have finished high school (16.3 versus 7.1 percent). 
${ }^{12}$ The negative relationship between in-migration and the change in wholesale earnings is statistically significant at conventional levels; the other two associations are not. The OLS coefficient for a regression of changes in wholesale earnings on in-migration rates is -0.608 (s.e. $=0.223$ ).

${ }^{13}$ We have also estimated the model in first differences using changes in the average annual earnings per employee in the manufacturing, retail and wholesale sectors between 1935 and 1939. The raw relationships are depicted graphically in Figure 1. While the direction of the relationship is comparable in the aggregate and individual data, the magnitude is highly sensitive to the inclusion of individual characteristics. Furthermore, the aggregate data do not allow us to distinguish between wages and work opportunities, a distinction that turns out to be important.

${ }^{14}$ City-level variables are taken from published Census data and aggregated to the metropolitan area level.

${ }^{15} 59$ percent of migrants in the late 1930s moved within the same state (U.S. Bureau of the Census, 1943).

${ }^{16}$ An alternative approach is to assign migrants to destinations based on settlements patterns established during a prior migration wave (see, for example, Card, 2001, Lewis, 2004, and Boustan, 2007). We did not follow this path because 1940 was the first year in which the Census Bureau asked residents about internal mobility.

${ }^{17}$ We aggregated county-level data from the New Deal project to match our sample of metropolitan areas and balance-of-state locations. See Fishback, Horrace, and Kantor (2006) and Fishback, Haines and Kantor $(2001,2007)$ for descriptions of the data.

${ }^{18}$ The "balance of state" designation refers to the portion of the state not contained in one of the large metropolitan area in the sample.

${ }^{19}$ We thank Trent Alexander and David Van Riper at the Minnesota Population Center for providing measures of distances in miles between every county group in the United States. We calculate the distance between balance-of-state areas as the average distance from every non-metropolitan county group in state A to every non-metropolitan county group in state B. A preferred measure may be the distance between the population-weighted centroids of each balance-of-state area. While this measure is feasible, it would be extremely time-intensive to produce and would correspond closely to our current method.

${ }^{20} \mathrm{We}$ also tried a specification in which the probability of a migrant from $j$ settling in $k$ depended on the logarithm of the distance between $j$ and $k$. The results did not change.

${ }^{21}$ We combined the number unemployed and seeking work and the number out of the labor force into the idle group because those out of the labor force included an inordinately large share of discouraged workers. The presence of large numbers of discouraged workers should not be surprising given that 14 percent of the labor force was officially unemployed or on work relief from 1935 through 1939.

${ }^{22}$ Some emergency relief jobs were offered through the Civilian Conservation Corps and the National Youth Administration or by state and local governments.

${ }^{23}$ The Works Progress Administration offered different monthly payments in urban and rural areas and across regions. The availability of relief jobs also varied across geographic districts. 
${ }^{24}$ We consider this number to be a conservative estimate because it assumes that the migration flow of the 1920s would have continued unabated in the 1930s if not for the Dust Bowl, a likely overstatement given that migration rates fell nationwide during the Depression. 